Jurnal Kesehatan Hesti Wira Sakti

ISSN 2302-4283 (print)

ISSN 2580-9571 (online)

Online di https://jurnal.poltekkes-soepraoen.ac.id

\title{
SIKAP CARING PERAWAT TERHADAP PASIEN RAWAT INAP
}

\author{
Cindi Dwi Sandiyah ${ }^{1,}$ Mustriwi ${ }^{2}$ \\ ${ }^{1}$ Klinik Rawat Inap Ronggo Husada Malang \\ ${ }^{2} \mathrm{RS}$ dr. Soepraoen Malang \\ (Korespondensi: cindysnd0@gmail.com)
}

\begin{abstract}
ABSTRAK
Pendahuluan: Pemberian pelayanan keperawatan didasari oleh sikap caring perawat yang mampu meningkatkan kualitas pelayanan keperawatan. Sikap caring merupakan suatu cara pendekatan yang dinamis, dimana perawat bekerja untuk lebih meningkatkan kepeduliannya kepada pasien. Tujuan penelitian ini adalah untuk mengetahui gambaran sikap caring perawat terhadap pasien rawat inap di Ruang Dahlia dan Unit Stroke Rumah Sakit dr. Soepraoen Malang. Metode: Penelitian ini merupakan penelitian kuantitatif dengan desain penelitian deskriptif. Populasi semua perawat di Ruang Dahlia dan Unit Stroke RS dr. Soepraoen Malang berjumlah 27 orang. Teknik sampling menggunakan total sampling didapatkan 27 sampel. Pengumpulan data menggunakan lembar kuesioner. Analisis menggunakan analisis univariat. Data disajikan dengan distribusi frekuensi. Hasil: Hasil penelitian menunjukkan sikap caring perawat di Ruang Dahlia dan Unit Stroke Rumah Sakit dr. Soepraoen Malang sebagian besar bersikap caring tinggi sebanyak 16 orang $(59,3 \%)$, hampir setengah bersikap caring sedang sebanyak 10 orang $(37 \%)$, dan sebagian kecil bersikap caring rendah sebanyak 1 orang $(3,7 \%)$. Kesimpulan: Perawat dengan usia yang lebih tua, pengalaman kerja yang lebih lama, dan perawat yang pernah disupervisi oleh atasan cenderung memiliki sikap caring tinggi. Melihat hasil penelitian yang telah dilakukan ini maka perlu meningkatkan pemahaman perawat terhadap pentingnya sikap caring terhadap pasien.
\end{abstract}

Kata kunci: sikap caring, perawat, pasien rawat inap

\begin{abstract}
Introduction: The provision of nursing services is based on the caring attitude of nurses who are able to improve the quality of nursing services. Caring attitude is a dynamic approach, where nurses work to increase their care for patients. The purpose of this study was to describe the caring attitude of nurses towards inpatients in Dahlia Room and Stroke Unit of dr. Soepraoen Malang. Methods: This research was a quantitative research with a descriptive research design. The population of all nurses in the Dahlia Room and the Stroke Unit of dr. Soepraoen Malang numbered 27 people. Sampling technique used a total sampling obtained 27 samples. Data collection used a questionnaire sheet. The analysis used univariate analysis. The data was presented with a frequency distribution. Results: The result showed the caring attitude of nurses in the Dahlia Room and Stroke Unit of dr. Soepraoen Malang mostly had high caring attitude as many as 16 people (59.3\%), almost half had moderate caring attitude as many as 10 people (37\%), and a small proportion had low caring attitude as many as 1 person (3.7\%). Conclusion Nurses with an older age, longer work experience, and nurses who had been supervised by superiors tend to have a high caring attitude. Seeing the results of this research, it is necessary to increase nurses' understanding of the importance of caring attitudes towards patients.
\end{abstract}

Keywords: caring attitude, nurses, inpatients

81 | Vol. 9 No. 2, Oktober 2021 


\section{PENDAHULUAN}

Pelayanan keperawatan adalah suatu bentuk pelayanan profesional yang merupakan bagian integral dari pelayanan kesehatan yang didasarkan pada ilmu dan kiat keperawatan ditujukan kepada individu, keluarga, kelompok, atau masyarakat, baik sehat maupun sakit (Undang-Undang Republik Indonesia Nomor 38 Tahun 2014). Pemberian pelayanan keperawatan juga didasari oleh sikap caring perawat yang mampu meningkatkan kualitas pelayanan keperawatan. Perawat mempunyai tugas untuk memberikan caring kepada pasien, yang dapat terwujud dengan perawat memberikan empati dan dukungan kepada pasien (Purwaningsih, 2018). Peran perawat dalam pelayanan kesehatan saat ini sedang mengalami "krisis caring" (Susilaningsih dkk., 2020). Faktanya belum semua perawat melayani pasien dengan caring seperti perawat bersikap kurang ramah, jarang tersenyum, dan mudah emosi jika ditanya oleh pasien ataupun keluarga pasien (Yuningsih dkk., 2015).

Berdasarkan fenomena yang ada dari berbagai macam kendala permasalahan dapat memunculkan stimulus ketidaknyamanan pasien selama dirawat di rumah sakit seperti pemberian informasi yang tidak jelas dari tim medis tentang penyakit pasien yang kurang diuraikan oleh perawat atau dokter. Hal ini memberikan sikap caring perawat yang tidak baik seperti komunikasi yang tidak baik, kasar, perawat yang tidak sigap dalam memberikan pengobatan pada pasien, tidak empati, lambat dalam bertindak sehingga terkesan kurang profesional (Sulistyorini, 2018).

Menurut penelitian secara kualitatif oleh Windarini (2014) di RSUD dr. Soediran Mangun Sumarso Wonogiri tentang sikap caring perawat dalam memberikan asuhan peperawatan, sikap caring hanya sebagai pemahaman saja tetapi belum diaplikasikan secara maksimal dalam pelayanan kepada pasien, penelitian Mailani dan Fitri (2017) di RSUD dr. Rasidin Padang didapatkan hasil dari 84 orang perawat sebanyak 39 orang $(46,4 \%)$ memiliki sikap caring buruk, sebanyak 24 orang $(28,6 \%)$ memiliki sikap caring cukup dan hanya sebanyak 21 orang $(25,0 \%)$ memiliki sikap caring baik. Hasil dari penelitian lain yang dilakukan oleh Aini dan Ariani (2018) di Ruang Melati Rumkit dr. Soepraoen Malang kepada 15 orang perawat sebanyak 6 orang (40\%) memiliki sikap caring baik dan mayoritas sikap caring perawat kurang sejumlah 9 orang (60\%). 
Dari hasil studi pendahuluan yang dilakukan peneliti pada tanggal 23 Desember 2020 di Ruang Dahlia Rumah Sakit dr. Soepraoen Malang, didapatkan data jumlah keseluruhan perawat di Ruang Dahlia adalah 14 perawat. Menurut hasil studi pendahuluan tentang sikap caring melalui google form, dari 5 orang perawat didapatkan 5 orang perawat menjawab selalu memperkenalkan diri kepada pasien, 3 dari 5 orang perawat selalu menemui pasien untuk menawarkan bantuan, 5 dari 5 orang perawat senantiasa mendampingi pasien saat pasien membutuhkan, 5 dari 5 orang perawat selalu memberikan perawatan dan pengobatan pada pasien dengan tepat waktu sesuai SOP yang ada, dan 5 dari 5 orang perawat selalu memberikan motivasi pasien untuk berfikir positif tentang kondisi sakitnya.

Caring merupakan suatu cara pendekatan yang dinamis, dimana perawat bekerja untuk lebih meningkatkan kepeduliannya kepada klien (Purwaningsih, 2018). Bentuk-bentuk sikap caring yang harus ada pada perawat antara lain sikap peduli terhadap pemenuhan kebutuhan klien, bertanggung jawab dalam memenuhi kebutuhan klien, ramah dalam melayani klien, sikap tenang dan sabar dalam melayani klien, selalu siap sedia memenuhi kebutuhan klien, memberi motivasi kepada klien, sikap empati terhadap klien (Dedi dkk., 2008).

Sikap caring dapat dipengaruhi oleh beberapa faktor. Secara garis besar, terbentuknya sikap caring dipengaruhi oleh faktor internal yang meliputi faktor genetik dan karakter seseorang, juga dipengaruhi oleh faktor eksternal yang meliputi: pendidikan, pengetahuan, pengalaman kerja dan beban kerja. Jika perawat merasa bimbang karena status kepegawaiannya yang belum mapan seperti masih bersifat sebagai tenaga honorer, merasa kuatir bila dilakukan PHK (Pemutusan Hubungan Kerja), atau perolehan gaji yang dirasa kurang. Hal ini bisa jadi berdampak pada sikap caring perawat (Yuningsih dkk., 2015). Kurangnya caring perawat dalam pelayanan keperawatan dapat berakibat penurunan mutu pelayanan keperawatan yang berdampak pada penurunan kepuasan pasien dan peningkatan hari rawat (Purwaningsih, 2018).

Sikap caring bisa dipelajari oleh semua perawat dan bukan merupakan sifat bawaan. Perawat memahami caring sebagai observasi dan tindakan yang sabar dan penuh perhatian yang menyebabkan kelegaan yang meningkat bagi pasiennya. Mereka mencoba memahami gejala pasien penyakit dan bahasa tubuh mereka melalui 
pengamatan dan penilaian fungsi vital, mengintegrasikan tujuan penting dan gejala subyektif dengan data lainnya (Aini dkk., 2018).

Untuk meningkatkan sikap caring perawat adalah dengan meningkatkan pemahaman perawat terhadap pentingnya sikap caring, memotivasi perawat untuk lebih meningkatkan kualitas caring dalam memberikan asuhan keperawatan, melakukan monitoring terhadap sikap caring perawat dalam melaksanakan asuhan keperawatan dengan mengedepankan prinsip caring serta memberikan kesempatan perawat untuk mendapatkan materi caring salah satunya dengan kegiatan pelatihan caring. Semakin baik sikap caring perawat dalam memberikan pelayanan keperawatan kepada pasien maka tingkat kepuasan pasien terhadap pelayanan keperawatan akan semakin baik juga (Suweko dkk., 2019). Pendidikan juga memiliki peranan penting untuk pengembangan keterampilan dalam memberikan pelayanan keperawatan atas dasar sikap caring sehingga dapat memberikan perawatan yang berorientasi pada kebutuhan pasien. Sikap caring tidak terbentuk secara otomatis tetapi harus dilatih dan dikembangkan sehingga perawat memiliki sikap caring terhadap pasien (Susilaningsih dkk., 2020).
Berdasarkan latar belakang di atas, peneliti tertarik untuk melakukan penelitian terkait gambaran sikap caring perawat terhadap pasien rawat inap di Ruang Dahlia dan Unit Stroke Rumah Sakit dr Soepraoen Malang.

\section{METODE PENELITIAN}

Desain penelitian yang digunakan dalam penelitian ini adalah deskriptif. Populasi penelitian adalah seluruh perawat di Ruang Dahlia dan Unit Stroke Rumah Sakit dr. Soepraoen Malang sejumlah 27 orang. Sampel pada penelitian ini adalah seluruh perawat di Ruang Dahlia dan Unit Stroke Rumah Sakit dr. Soepraoen Malang sejumlah 27 orang yang didapatkan dengan teknik total sampling. Variabel dalam penelitian ini yaitu Sikap caring perawat terhadap pasien rawat inap. Data diambil dengan kuesioner yang terdiri atas 27 butir pernyataan yang terdiri dari 19 pernyataan positif dan 8 pernyataan negatif dengan pilihan jawaban yang terdiri dari selalu, sering, jarang, dan tidak pernah. Pernyataan positif selalu skor 3, sering skor 2 , jarang skor 1 , tidak pernah skor 0 , pernyataan negatif selalu skor 0 , sering skor 1 , jarang skor 2, tidak pernah skor 3 sehingga skor tertinggi adalah 81, sedangkan skor terendah adalah 0 . Kriteria perilaku dikategorikan menjadi tinggi (>76\%), sedang (56-76\%), dan rendah 
$(<56 \%)$. Responden diberikan inform consent sebelum penelitian dilakukan. Analisis data menggunakan analisis univariat. Data disajikan dalam distribusi frekuensi dengan bantuan SPSS 22.0.

\section{HASIL PENELITIAN}

Berdasarkan data karakteristik responden pada Tabel 1 menunjukkan bahwa sebagian besar di Ruang Dahlia dan Unit Stroke Rumah Sakit dr. Soepraoen Malang berusia 26-35 tahun sebanyak 14 orang $(51,9 \%)$, sebagian besar responden berjenis kelamin perempuan di Ruang Dahlia dan Unit Stroke Rumah Sakit dr. Soepraoen Malang sebanyak 15 orang $(55,6 \%)$, sebagian besar berpendidikan D3 Keperawatan di Ruang Dahlia dan Unit Stroke Rumah Sakit dr. Soepraoen Malang sebanyak 20 orang $(74,1 \%)$, hampir seluruh responden sudah menikah di Ruang Dahlia dan Unit Stroke Rumah Sakit dr. Soepraoen Malang sebanyak 23 orang $(85,2 \%)$, sebagain besar responden berstatus Non PNS di Ruang Dahlian dan Unit Stroke Rumah Sakit dr. Soepraoen Malang sebanyak 19 orang $(70,4 \%)$, sebagian besar berperan sebagai perawat pelaksana di Ruang Dahlia dan Unit Stroke Rumah Sakit dr. Soepraoen Malang sebanyak 20 orang $(74,1 \%)$, hampir setengah pengalaman kerja sebagai perawat 4-6 tahun dan >10 tahun di Ruang
Dahlia dan Unit Stroke Rumah Sakit dr. Soepraoen Malang sebanyak 11 orang (40,7\%), hampir seluruhnya responden pernah di supervisi oleh atasan di Ruang Dahlia dan Unit Stroke Rumah Sakit dr. Soepraoen Malang sebanyak 22 orang $(81,5 \%)$.

Sedangkan sikap caring perawat terhadap pasien rawat inap berdasarkan data karakteristik responden pada tabel 2 menunjukkan sebagian besar bersikap caring tinggi sebanyak 16 orang (59,3\%), hampir setengah bersikap caring sedang sebanyak 10 orang (37\%), dan sebagian kecil bersikap caring rendah sebanyak 1 orang $(3,7 \%)$.

\section{PEMBAHASAN}

Berdasarkan hasil penelitian yang dilakukan mengenai gambaran sikap caring perawat terhadap pasien rawat inap di Ruang Dahlia dan Unit Stroke Rumah sakit dr. Soepraoen Malang diperoleh data bahwa sebagian besar perawat bersikap caring tinggi. Perawat dengan usia, pengalaman kerja, dan pernah tidaknya disupervisi oleh atasan cenderung memiliki sikap caring yang tinggi. 
Tabel 1. Karakteristik Responden

\begin{tabular}{|c|c|c|}
\hline Data Umum & $\mathbf{N}$ & $\%$ \\
\hline \multicolumn{3}{|l|}{ Usia } \\
\hline 17-25 Tahun (Remaja Akhir) & 1 & $3,7 \%$ \\
\hline 26-35 Tahun (Dewasa Awal) & 14 & $51,9 \%$ \\
\hline 36-45 Tahun (Dewasa Akhir) & 8 & $29,6 \%$ \\
\hline 46-55 Tahun (Lansia Awal) & 4 & $14,8 \%$ \\
\hline \multicolumn{3}{|l|}{ Jenis Kelamin } \\
\hline Laki-laki & 12 & $44,4 \%$ \\
\hline Perempuan & 15 & $55,6 \%$ \\
\hline \multicolumn{3}{|l|}{ Pendidikan } \\
\hline D3 Keperawatan & 20 & $74,1 \%$ \\
\hline D4 Keperawatan & 0 & $0 \%$ \\
\hline S1 Keperawatan & 7 & $25,9 \%$ \\
\hline S2 Keperawatan & 0 & $0 \%$ \\
\hline \multicolumn{3}{|l|}{ Status Pernikahan } \\
\hline Belum Menikah & 4 & $14,8 \%$ \\
\hline Menikah & 23 & $85,2 \%$ \\
\hline Lainnya & 0 & $0 \%$ \\
\hline \multicolumn{3}{|l|}{ Status Kepegawaian } \\
\hline PNS & 8 & $29,6 \%$ \\
\hline Non PNS & 19 & $70,4 \%$ \\
\hline \multicolumn{3}{|l|}{ Peran Perawat } \\
\hline Kepala Ruangan & 2 & $7,4 \%$ \\
\hline Ketua Tim & 5 & $18,5 \%$ \\
\hline Perawat Pelaksana & 20 & $74,1 \%$ \\
\hline \multicolumn{3}{|l|}{ Pengalaman Kerja } \\
\hline$<1$ tahun & 1 & $3,7 \%$ \\
\hline 1-3 tahun & 0 & $0 \%$ \\
\hline 4-6 tahun & 11 & $40,7 \%$ \\
\hline 7-10 tahun & 4 & $14,9 \%$ \\
\hline$>10$ tahun & 11 & $40,7 \%$ \\
\hline \multicolumn{3}{|l|}{ Di Supervisi } \\
\hline Pernah & 22 & $81,5 \%$ \\
\hline Tidak Pernah & 5 & $18,5 \%$ \\
\hline Total & 27 & $100 \%$ \\
\hline
\end{tabular}

Tabel 2. Sikap Caring Perawat terhadap Pasien Rawat Inap di Ruang Dahlia dan Unit Stroke Rumah sakit dr. Soepraoen Malang

\begin{tabular}{ccc}
\hline Kategori & $\mathbf{N}$ & $\mathbf{\%}$ \\
\hline Tinggi & 16 & $59,3 \%$ \\
Sedang & 10 & $37 \%$ \\
Rendah & 1 & $3,7 \%$ \\
\hline Total & $\mathbf{2 7}$ & $\mathbf{1 0 0 \%}$ \\
\hline
\end{tabular}

Ada tiga faktor yang dapat mempengaruhi sikap caring, yaitu: faktor individu (kemampuan, keterampilan, latar belakang, dan demografis meliputi usia, jenis kelamin, latar belakang pendidikan, masa kerja, status perkawinan, dan status kepegawaian), faktor psikologis (sikap, kepribadian, belajar, motivasi), faktor organisasi (sumberdaya manusia, kepemimpinan, supervisi, imbalan, struktur dan pekerjaan) (Kusnanto, 2019). Faktor yang dapat mempengaruhi sikap caring perawat terhadap pasien rawat inap dalam penelitian ini adalah usia, pengalaman kerja, dan pernah tidaknya disupervisi oleh atasan.

Menurut Wahyudi (2016) bahwa semakin muda usia perawat, tingkat caring makin rendah. Kondisi ini dipengaruhi oleh faktor perkembangan, dimana usia muda masih belum mampu mengendalikan emosional pribadinya. Pendapat lain di kemukakan oleh Desslerr (2000), bahwa usia produktif adalah usia 25-45 tahun. Tahap ini merupakan penentu seseorang untuk memilih bidang pekerjaan yang sesuai dengan karir individu tersebut. Menurut peneliti lebih muda usia responden cenderung belum mampu mengendalikan emosi dan belum bijaksana dalam mengambil keputusan dibandingkan dengan usia yang lebih tua. Sehingga dalam penelitian ini, usia yang lebih tua cenderung memiliki sikap caring tinggi. Pengalaman bekerja dapat membentuk 
seorang perawat berperilaku caring yang baik sesuai dengan persepsi pasien, terutama kemampuan perawat dalam berkomunikasi dengan pasien. Perawat yang besifat caring dalam membina hubungan dengan orang lain juga harus menunjukkan sikap empati dan mudah didekati serta mau mendengarkan orang lain.

Perawat perlu dilakukan supervisi guna meningkatkan kualitas pelayanan perawatan juga menunjukkan bahwa kelompok yang dilakukan intervensi supervisi memiliki peningkatan kualitas pelayanan yang dirasakan oleh pasiennya. Hal tersebut sesuai dengan teori bahwa pernah tidaknya disupervisi akan mempengaruhi kualitas pelayanan serta sikap caring perawat terhadap pasien.

Upaya untuk meningkatkan sikap caring perawat terhadap pasien rawat inap perlu dilakukan peningkatan pemahaman perawat terhadap pentingnya sikap caring, memotivasi perawat untuk lebih meningkatkan kualitas caring dalam memberikan asuhan keperawatan, melakukan monitoring terhadap sikap caring perawat dalam melaksanakan asuhan keperawatan dengan mengedepankan prinsip caring serta memberikan kesempatan perawat untuk mendapatkan materi caring salah satunya dengan kegiatan pelatihan caring (Suweko dkk., 2019).

\section{KESIMPULAN}

Berdasarkan hasil penelitian yang dilakukan mengenai gambaran sikap caring perawat terhadap pasien rawat inap di Ruang Dahlia dan Unit Stroke Rumah sakit dr. Soepraoen Malang dapat disimpulkan bahwa sebagian besar bersikap caring tinggi.

Perawat dengan usia yang lebih tua, pengalaman kerja yang lebih lama, dan perawat yang pernah disupervisi oleh atasan cenderung memiliki sikap caring tinggi. Berdasarkan hasil tersebut disarankan Rumah sakit sebaiknya memberikan penghargaan bagi perawat yang memiliki prestasi dalam bidang tertentu untuk meningkatkan sikap caring perawat. Diharapkan responden dapat meningkatkan sikap caring seperti melaksanakan 3S (senyum, salam sapa) terhadap pasien rawat inap.

\section{DAFTAR PUSTAKA}

Aini, Nur, dan Tutu April Ariani. 2018. Hubungan Tipe Kepribadian dan Budaya Organisasi terhadap Perilaku Caring Perawat. Jurnal Kesehatan Hesti Wira Sakti, 2(6), 1-11.

Aminuddin. 2011. Hubungan Iklim Kerja dengan Kinerja Perawat Pelaksana di Ruang Rawat Inap RSUD dr. Yunus 
Bangkulu. Tesis Program Magister Ilmu Keperawatan FIK UI.

Arikunto, S. 2013. Prosedur Penelitian: Suatu pendekatan Praktik. Jakarta: Rineka Cipta.

Azwar, Saifuddin MA., 2013. Sikap Manusia: Teori dan Pengukurannya. Yogyakarta: Pustaka Pelajar.

Dedi, Blacius, Setyowati, dan Yati Afiyanti. 2008. Perilaku Caring Perawat Pelaksana di sebuah Rumah Sakit di Bandung: Studi Grounded Theory. Jurnal Keperawatan Indonesia, 12(1), 40-46.

Dessler, Gary. 2000. Human Resource Management $8^{\text {th }}$ Edition. New Jersey: Prentice-Hall, Inc.

Dewi, Yulianti Kurnia. 2017. Gambaran Perilaku Caring Perawat di Ruang Paviliun dan Ruang Rawat Inap Kelas III Rumah sakit Daerah dr. Soebandi Jember. Skripsi. Fakultas Ilmu Keperawatan. Universitas Jember: Jember.

Istiqomah. 2018. Hubungan Sikap caring Perawat dengan Pelaksanaan Oral Hygiene pada Pasien Stroke Berbasis Teori Swanson di Ruang Flamboyan RSUD Jombang. Skripsi. Program Studi Ilmu Keperawatan. Stikes Insan Cendekia Medika: Jombang.

Kementerian Kesehatan RI. 2012. Pedoman Teknis Bangunan Rumah Sakit Ruang Rawat Inap.

Kusnanto. 2019. Perilaku Caring Perawat Profesional. Surabaya: Pusat Penerbitan dan Percetakan Universitas Airlangga (AUP).

Lazzerini, M et al. 2017. Improving the Quality of Hospital Care for Children by Supportive Supervision: a Cluster Randomized Trial Kyrgyzstan. Bulletin of the World Health Organization, vol 95, 397-407.
Mailani, Fitri, dan Nera Fitri. 2017. Hubungan Perilaku Caring Perawat dengan Tingkat Kepuasan Pasien BPJS di RSUD dr. Rasidin Padang. Jurnal Endurance, 2(2), 203-208.

Menteri Kesehatan Republik Indonesia. 2008. Undang-Undang Republik Indonesia Nomor 129 Tahun 2008 tentang Standar Pelayanan Minimal Rumah Sakit. Lembaran Negara Republik Indonesia. Jakarta: Sekretariat Negara.

Muttaqin, Z. 2008. Jurnal Keperawatan Indonesia: Pengaruh Pelatihan Supervisi pada Kepala Ruangan terhadap Perilaku Caring Perawat Pelaksana. Tesis, http://www.lib.ui.ac.id.

Notoatmodjo, Soekidjo. 2018. Metodologi Penelitian Kesehatan. Jakarta: PT Rineka Cipta.

Nursalam. 2011. Konsep dan Penerapan Metodologi Penelitian Ilmi Keperawatan. Jakarta: Salemba Medika.

Nursalam. 2013. Metodologi Penelitian ilmu Keperawatan: Pendekatan Praktis Edisi 3. Jakarta: Salemba Medika.

Pemerintah Indonesia. 2014. UndangUndang Republik Indonesia Nomor 38 Tahun 2014 tentang Keperawatan. Lembaran Negara Republik Indonesia Nomor 5612. Jakarta: Sekretariat Negara.

Purwaningsih, Diah Fitri. 2018. Perilaku Caring Perawat Pelaksana di Ruang Rawat Inap. Jurnal Ilmiah Kesehatan, 61-67.

Riani, A. 2011. Budaya Organisasi. Yogyakarta: Graha Ilham.

Rukajat, Ajat. 2018. Pendekatan Penelitian Kuantitatif. Yogyakarta: CV Budi Utama. 
Siagian, Sondang P. 2010. Manajemen Sumber Daya Manusia. Jakarta: Bumi Aksara.

Sugiyono. 2017. Metode Penelitian Kuantitatif, Kualitatif, dan $R \& D$. Bandung: Alfabeta, CV.

Sulistyorini. 2018. Pengaruh Pelatihan Sepuluh Carative Caring Terhadap Perilaku Caring dan Motivasi Perawat di Instalasi Rawat Inap Rumah Sakit Islam Surabaya. Skripsi. Universitas Nahdlatul Ulama: Surabaya.

Susilaningsih, Francisca Sri, Valentina Belinda, dan Marisa Mar'atus Sholihah. 2020. Hubungan Kecerdasan Emosional dengan Sikap Caring Mahasiswa Keperawatan Universitas Padjadjaran. Jurnal Keperawatan Komprehensif, 6(1), 1-69.

Suweko, Hadi, dan Bambang Edi Warsito. 2019. Hubungan Perilaku Caring Perawat dengan Kepuasan Pasien di Ruang Rawat Inap: Literatur Review. Jurnal Ilmu Keperawatan dan Kebidanan, 10(1), 243-247.

Wahyudi. 2016. Faktor-Faktor yang Berhubungan dengan Perilaku Caring Perawat di Ruang Perawatan Interna RSUD Sinjai. Skripsi. Universitas Islam Negeri Alauddin: Makassar.

Widjaya, Lily, dan Deasy Rosmaladewi. 2017. Manajemen Informasi Keselamatan II: Sistem dan Sub Sistem Pelayanan RMIK. Jakarta: Kementerian Kesehatan Republik Indonesia.

Windarii, Luciana. 2014. Sikap Caring Perawat dalam Memberikan Asuhan Keperawatan pada Pasien di Ruang Intensif Care Unit (ICU) RSUD dr. Soediran Mangun Sumarso Kabupaten Wonogiri. Skripsi. Program Studi Keperawatan. Stikes Kusuma Husada: Surakarta.
Yuningsih, Diah Yentina Astri, Komaruddin, Asmuji, dan Supriyadi. 2015. Hubungan Status Kepegawaian Perawat dengan Perilaku Caring Perawat pada Pasien di Ruang Rawat Inap Kelas 3 RSD Balung Jember. Skripsi. Fakultas ilmu Kesehatan. Universitas Muhamadiyah: Jember. 